\title{
IDENTIFIKASI PATAHAN MANADO DENGAN MENGGUNAKAN METODE GEOLISTRIK RESISTIVITAS KONFIGURASI WENNER-SCHLUMBERGER DI DESA WATUTUMOU II KECAMATAN KALAWAT KABUPATEN MINAHASA UTARA
}

\author{
Faisal Mamonto ${ }^{1)}$, As'ari $^{1)}$, Ferdy $^{1)}$ \\ ${ }^{1)}$ Program Studi Fisika FMIPA UNSRAT \\ Jl. Kampus Unsrat, Manado 95115 \\ Email : faisal_mamonto@ymail.com; as.ari2222@yahoo.co.id ; fsagita12@yahoo.com
}

\begin{abstract}
ABSTRAK
Telah dilakukan penelitian tentang Identifikasi Patahan Manado yang melewati Desa Watutumou II Kecamatan Kalawat Kabupaten Minahasa Utara. Penelitian dilakukan dengan menggunakan alat Geolistrik Resistivitas multichannel and multielectrode resistivity and IP meter 46 simultaneous channel merek MAE X612-EM Konfigurasi Wenner-Schlumberger. Pengambilan data dilakukan pada 4 lintasan, 3 lintasan panjang bentangannya sebesar 480 meter, dan 1 lintasan panjang bentangannya sebesar 240 meter. Posisi lintasan disusun parallel satu dengan yang lain. Pengolahan data dilakukan dengan mengunakan perangkat lunak RES2DINV, menghasilkan gambar tampang lintang 2 dimensi citra bawah permukaan tanah pada lokasi penelitian. Analisis menunjukan bahwa pada semua lintasan rekahan teridentifikasi pada jarak 20 meter dari jalur Patahan Manado, dengan kedalaman 0 - 30 meter dari permukaan tanah, dan harga resistivitas sebesar $0-80 \Omega \mathrm{m}$.
\end{abstract}

Kata Kunci : Geolistrik, Wenner-Schlumberger, Patahan Manado.

\section{IDENTIFICATION OF MANADO FAULT BY USING GEOELECTRICAL METHOD OF WENNER-SCHLUMBERGER RESISTIVITY CONFIGURATION IN THE VILLAGE OF WATUTUMOU II, DISTRICT OF KALAWAT, NORTH MINAHASA REGANCY}

\begin{abstract}
Has done research on the identification of Manado Fault which passes through the village of Watutumou II Kalawat district of North Minahasa Regency. Research is done by using the tool of Geoelectrical Resistivity multichannel and multielectrode and IP meter 46 simultaneous channel Wenner-Schlumberger configuration with brand of MAE X612-EM. The data collection was carried out on 4 lanes, where 3 of them have a range of length of 480 meter and 1 lane with length of 240 meter. Each of these lanes was assembled paralelly one another. The data processing was held with assistance of RES2DINV software. Its result gave an overview about the 2-dimensional transection of beneath-surface imaging in the research zone. According to the analysis outcome, a fracture identified at 20 meter from the Manado fault, with a depth of 0-30 meter above the ground's surface, and with an approximated value of resistivity of $0-80 \Omega \mathrm{m}$.
\end{abstract}

Keywords: Geoelectric, Wenner-Shlumberger, Manado fault.

\section{PENDAHULUAN}

Indonesia adalah salah satu negara di dunia yang dilewati oleh cincin api (ring of fire). Indonesia juga terletak pada pertemuan tiga lempeng besar dunia, yaitu
Lempeng Eurasia, Lempeng Pasifik, dan Lempeng Indo-Australia, serta satu lempeng kecil yaitu Lempeng Philipina. Di Indonesia sendiri, Pulau Sulawesi khususnya bagian utara merupakan wilayah yang lokasinya berada persis di pertemuan tiga lempeng 
besar serta satu lempeng kecil tersebut. Hal itu membuat wilayah Sulawesi Utara mempunyai potensi rawan untuk terjadi gempabumi. Berdasarkan informasi dari peta geologi, Sulawesi Utara juga dilalui oleh beberapa patahan yang suatu saat dapat aktif dan berpotensi menimbulkan gempa bumi. Sehingga, kondisi seperti ini harus diwaspadai. Menurut Efendi dan Bawono (1997) patahan-patahan tersebut adalah Patahan Gorontalo, Patahan Amurang, Patahan Bolaang Mongondow dan Patahan Manado.

Geologi daerah Sulawesi Utara didominasi oleh batugamping sebagai satuan pembentuk cekungan sedimen Ratatotok. Satuan batuan lainnya adalah kelompok breksi dan batupasir, terdiri dari breksikonglomerat kasar, berselingan dengan batupasir halus-kasar, batu lanau dan batu lempung yang didapatkan di daerah Ratatotok-Basaan, serta breksi andesit piroksen. Kelompok Tuf Tondano berumur Pliosen terdiri dari fragmen batuan volkanik kasar andesitan mengandung pecahan batu apung, tuf, dan breksi ignimbrit, serta lava andesit-trakit. Batuan Kuarter terdiri dari kelompok Batuan Gunung api Muda terdiri atas lava andesit-basal, bom, lapili dan abu. Kelompok batuan termuda terdiri dari batugamping terumbu koral, endapan danau dan sungai serta endapan aluvium. Sirtu atau batu kali banyak terdapat di daerah sungai Buyat yang diusahakan oleh penduduk setempat sebagai bahan pondasi bangunan (Sompotan, 2012)

Menurut Peta Geologi lembar Manado, patahan Manado yang melintasi wilayah Kota Manado diperkirakan berada pada lokasi tepat di bawah kota Manado-Ketang-Sarongsong-Paslaten-

Karegesan-Tontalete pada satu garis lurus (Effendi dan Bawono, 1997).

\section{Kekar (Joint)}

Menurut Noor (2009), Kekar adalah struktur rekahan yang terbentuk pada batuan akibat suatu gaya yang bekerja pada batuan tersebut dan belum mengalami pergeseran. Kekar biasanya sering digunakan untuk menunjukkan perubahan secara relatif terusmenerus dari patahan (fracture) yang merupakan sebuah bidang yang telah mengalami pergerakan secara tidak terlihat.
Struktur kekar dapat dikelompokkan berdasarkan sifat dan karakter rekahan serta arah gaya yang bekerja pada batuan tersebut. Secara umum kekar dicirikan oleh beberapa faktor, yaitu :

1. Mempunyai struktur yang memotong bidang perlapisan batuan.

2. Terdapat mineral-mineral yang mengisi ruang pada bidang rekahannya.

3. Memiliki kenampakan Breksiasi (zona Hancuran).

Sedangkan untuk jenis-jenisnya kekar dikelompokan menjadi 3 jenis, jenis kekar yang umumnya dijumpai pada batuan adalah sebagai berikut :

1. Shear Joint (Kekar Gerus) adalah retakan atau rekahan yang membentuk pola saling berpotongan membentuk sudut lancip dengan arah gaya utama. Kekar jenis shear joint umumnya bersifat tertutup.

2. Tension Joint ( Kekar Tarik) adalah retakan atau rekahan yang berpola sejajar dengan arah gaya utama, Umumnya bentuk rekahan bersifat terbuka.

3. Extension Joint (Release Joint) adalah retakan atau rekahan yang berpola tegak lurus dengan arah gaya utama dan bentuk rekahan umumnya terbuka.

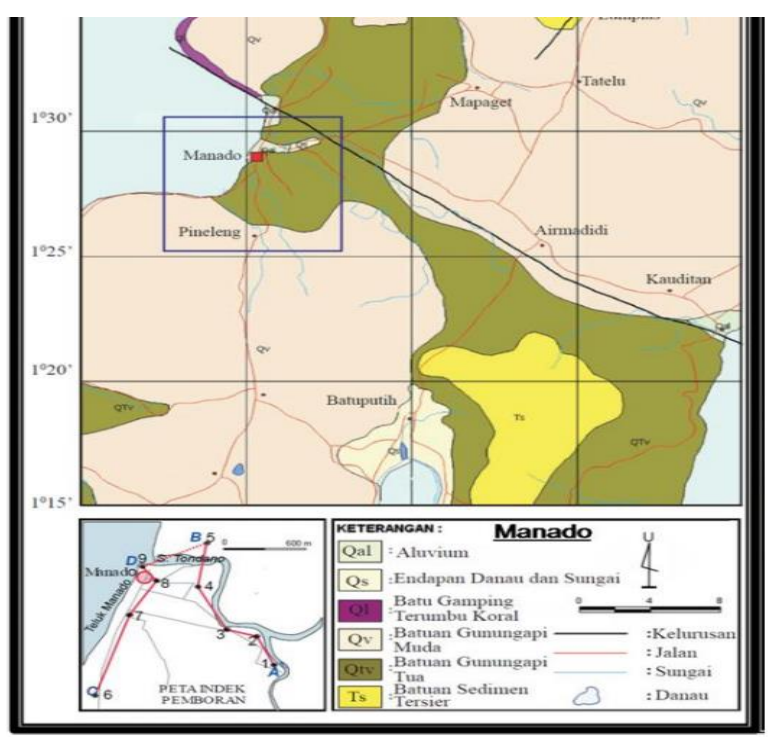

Gambar 1. Peta Geologi Lembar Manado (Sompotan,2012) 


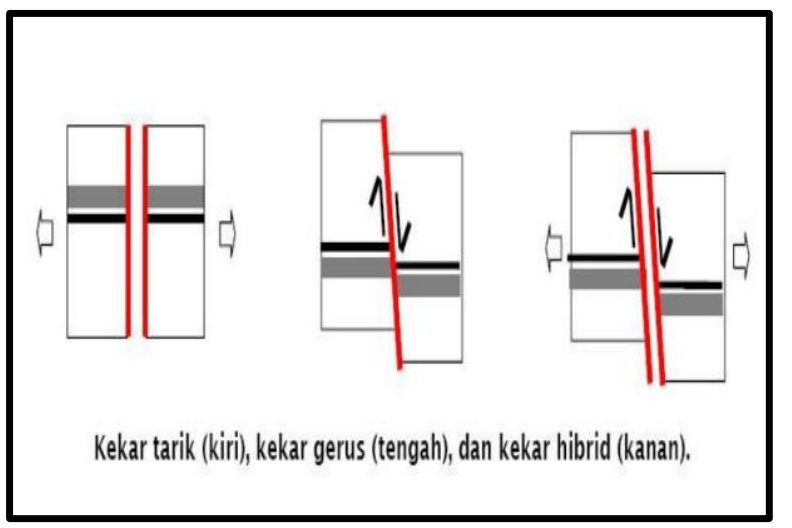

Gambar 2. Blok Diagram Kekar (documents.html)

\section{Sesar (Fault)}

Menurut Noor (2009), Sesar adalah struktur rekahan yang telah mengalami pergeseran. Umumnya disertai oleh struktur yang lain seperti lipatan dan rekahan. Patahan terjadi ketika suatu batuan mengalami retakan terlebih dahulu yang kejadian ini berkaitan erat dengan tekanan dan kekuatan batuan yang mendapatkan gaya sehingga timbul adanya retakan (fracture).

Sesar juga merupakan suatu bentuk rekahan pada lapisan batuan bumi yang menyebabkan satu blok batuan bergerak relatif terhadap blok yang lain. Pergerakan bisa relatif turun, relatif naik, ataupun bergerak relatif mendatar terhadap blok yang lain. Pergerakan yang tiba-tiba dari suatu patahan atau sesar bisa mengakibatkan gempa bumi (Lutfinur, 2015).

Berdasarkan pergeserannya, struktur sesar dalam geologi dikenal ada tiga jenis, yaitu :

1. Sesar Mendatar (Strike-slip Fault)

Sesar mendatar adalah sesar yang pergerakannya sejajar, blok bagian kiri relatif bergeser kearah yang berlawanan dengan blok bagian kanannya. Berdasarkan arah pergerakan sesarnya, sesar mendatar dapat dibagi menjadi 2 jenis sesar yaitu Sesar Mendatar Dextral (sesar mendatar menganan) dan Sesar Mendatar Sinistral (sesar mendatar mengiri). Pada Gambar 2.3 dapat dilihat bahwa Pergeseran pada sesar mendatar dapat sejajar dengan permukaan sesar atau pergeseran sesarnya dapat membentuk sudut (dip-slip/oblique). Sedangkan bidang sesarnya sendiri dapat tegak lurus maupun menyudut dengan bidang horizontal.

\section{Sesar Naik (Thrust Fault)}

Sesar naik adalah sesar dimana salah satu blok batuan bergeser ke arah atas dan blok bagian lainnya bergeser ke arah bawah disepanjang bidang sesarnya. Pada umumnya bidang sesar naik mempunyai kemiringan lebih kecil dari $45^{\circ}$, Pada Gambar 2.3 dapat dilihat bahwa salah satu bagian yang patah naik, dan bagian lainya tetap. Hal ini mengakibatkan penyempitan dari keadaan luas sebelumnya. Patahan jenis ini biasanya terjadi pada daerah tertekan, yakni di daerah pertemuan lempeng yang salah satu lempeng ditekan oleh lempeng lainya.

\section{Sesar Turun (Normal fault)}

Sesar turun adalah sesar yang terjadi karena pergeseran blok batuan akibat pengaruh gaya gravitasi. Secara umum, sesar normal terjadi sebagai akibat dari hilangnya pengaruh gaya sehingga batuan menuju ke posisi seimbang (isostasi). Sesar normal dapat terjadi dari kekar tension, release maupun kekar gerus. Pola pergerakan sesar turun dapat dilihat pada Gambar 2.3.

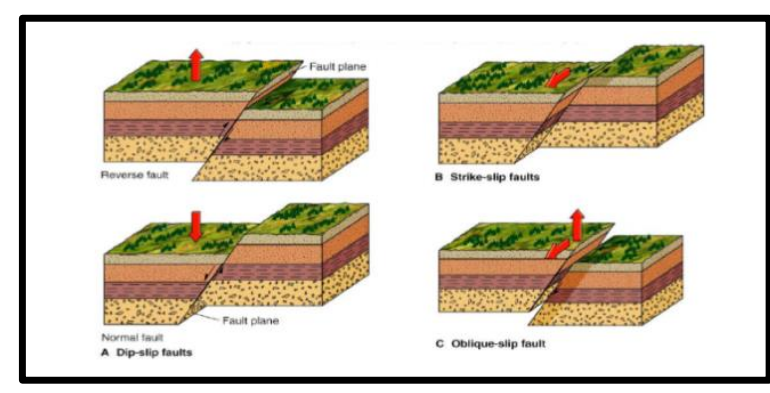

Gambar 3 Blok Diagram Sesar (Noor, 2009).

\section{Metode Geolistrik}

Metode geolistrik adalah bagian dari metode geofisika untuk mendeteksi kondisi bawah permukaan dengan menginjeksikan arus listrik melalui elektroda arus dan menghasilkan tahanan jenis dari berbagai material batuan. Kedalaman yang diperoleh tergantung bentangan kabel di lapangan, sehingga besar arus yang dipantulkan akan semakin dalam 
sejalan dengan semakin panjang bentangan (Waluyo dan Utama, 2009).

Penggunaan geolistrik pertama kali dilakukan oleh Conrad Schlumberger pada tahun 1912. Geolistrik merupakan salah satu metode geofisika untuk mengetahui perubahan tahanan jenis lapisan batuan bawah permukaan tanah dengan cara mengalirkan arus DC yang mempunyai tegangan tinggi kedalam tanah. Metode geolistrik resistivitas ini terdapat 2 macam metode dalam pengambilan datanya, yaitu metode geolistrik resistivitas mapping dan metode geolistrik resistivitas sounding. Metode resistivitas mapping merupakan metode resistivitas yang bertujuan untuk mempelajari variasi resistivitas lapisan tanah bawah permukaan secara horizontal. Sedangkan metode geolistrik resistivitas sounding bertujuan untuk mempelajari variasi resistivitas batuan di dalam permukaan bumi secara vertikal.

Resistivitas ditentukan dari suatu tahanan jenis semu yang dihitung dari pengukuran beda potensial antar elektroda yang ditempatkan dibawah permukaan tanah. Pengukuran beda potensial antara dua elektroda dapat dilihat seperti pada Gambar 2.4 dimana beda potensial yang terukur adalah hasil dari dua buah elektroda arus $\mathrm{C}$ yang merambat melalui medium tanah dengan nilai resistivitas tertentu dan akhirnya sampai dan terekam pada elektroda potensial P. (Todd, 1959).

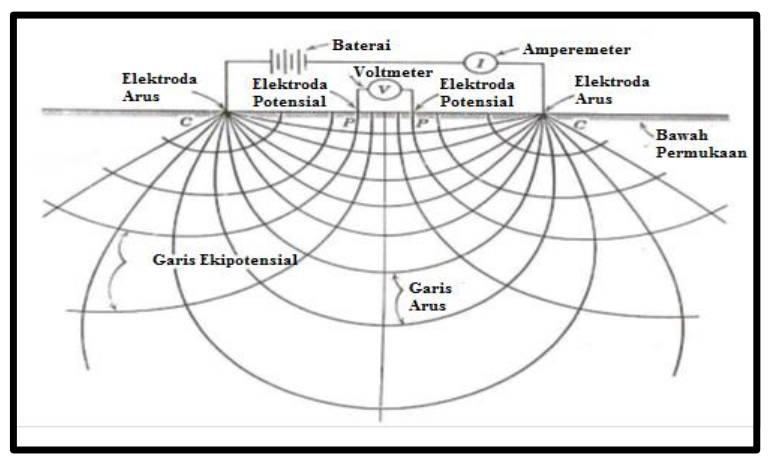

Gambar 4 Garis arus listrik dan medan potensial yang timbul karena adanya dua sumber arus listrik (Todd, 1959).

\section{Konfigurasi Wenner-Shclumberger}

Konfigurasi ini merupakan perpaduan dari konfigurasi Wenner dan konfigurasi Schlumberger. Pada pengukuran dengan faktor spasi $n=1$, konfigurasi Wenner-Schlumberger sama dengan pengukuran pada konfigurasi Wenner (jarak antar elektroda $=a$ ), namun pada pengukuran dengan $n=2$ dan seterusnya, konfigurasi Wenner-Schlumberger sama dengan konfigurasi Schlumberger.

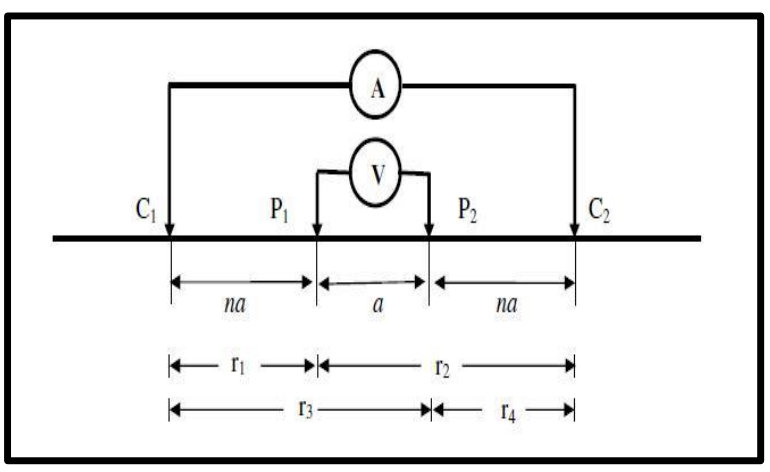

Gambar 5 Konfigurasi Wenner-Schlumberger

Pada konfigurasi ini, jarak antar elektroda a harus seragam untuk setiap pengukuran. Bila jarak antara elektroda $\mathrm{C} 1$ dan $\mathrm{C} 2$ adalah $12 \mathrm{~m}$, maka jarak elektroda P1 dan P2 adalah $4 \mathrm{~m}$ dan demikian seterusnya. Dari gambar, dapat diperoleh besarnya faktor geometri untuk konfigurasi Wenner adalah :

$$
K_{w}=2 \pi a
$$

Sehingga pada konfigurasi Wenner berlaku hubungan

$$
\rho_{0}=2 \pi a \frac{\Delta V}{I} \ldots \ldots \ldots
$$

Menurut (Sumanovac et al 2007), konfigurasi Wenner-Sclumberger mempuyai penetrasi maksimum hingga kedalaman 90 meter sedangkan konfigurasi Wenner hanya mencapai $80 \mathrm{~m}$. Variabel $n$ merupakan kelipatan untuk menunjukkan tingkat lapisan yang teramati.

Faktor geometri dari konfigurasi elektroda Wenner-Schlumberger adalah :

$$
K_{w-s}=\pi(n+1) a \ldots \ldots
$$

Dimana $a$ adalah jarak antara elektroda P1 dan P2, serta $n$ adalah perbandingan antara jarak elektrode C1-P1 dengan P1-P2 (misal 3a, maka $n=3$ ). Sehingga, nilai resistivitas semu dirumuskan : $\rho_{0}=\pi(n+1) a \frac{\Delta V}{I} \ldots \ldots .$. 


\section{METODE PENELITIAN}

\section{Waktu dan Tempat}

Penelitian dilaksanakan dengan proses pengamatan dan pengukuran secara langsung di Desa Watutumow II, Kecamatan Kalawat, Kabupaten Minahasa Utara. Secara geografis lokasi penelitian berada pada koordinat $\left(1^{\circ} 27^{\prime} 45,60^{\prime \prime} \quad\right.$ - $\left.1^{\circ} 27^{\prime} 38,58^{\prime \prime}\right) \quad$ LU dan (124 $\left.55^{\prime} 1,00^{\prime \prime}-124^{\circ} 54^{\prime} 59,88^{\prime \prime}\right)$ BT. Adapun peta lokasi penelitian dapat dilihat pada Gambar 6.

Waktu pelaksanaan pengambilan data dilakukan pada tanggal 16 Februari 2016, sedangkan untuk waktu pengolahan data dimulai pada bulan Maret - Juni 2016 dan dilaksanakan di Laboratorium Geofisika Jurusan Fisika FMIPA UNSRAT.

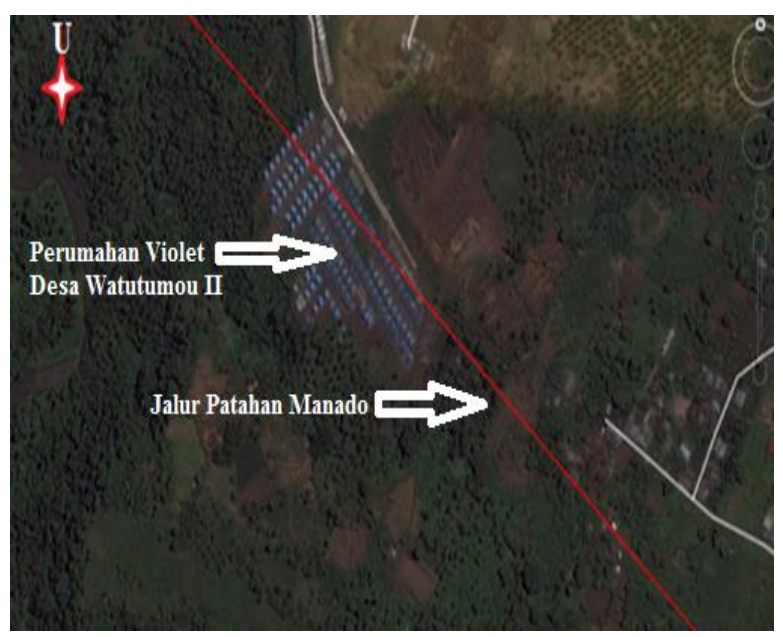

Gambar 6 Peta lokasi penelitian di Desa Watutumou II Kecamatan Kalawat Kabupaten Minut

Pengukuran dilakukan pada 4 lintasan dengan jarak spasi elektroda 10 meter. Pada lintasan 1, 2 dan 3 terdiri dari 48 elektroda dengan panjang lintasan 480 meter. Sedangkan untuk lintasan 4 terdiri dari 24 elektroda dengan panjang lintasan 240 meter. Masing-masing lintasan disusun parallel satu dengan yang lain dan membentuk sudut $45^{\circ}$ terhadap arah utara. Adapun pola desain survei dapat dilihat pada Gambar 7.

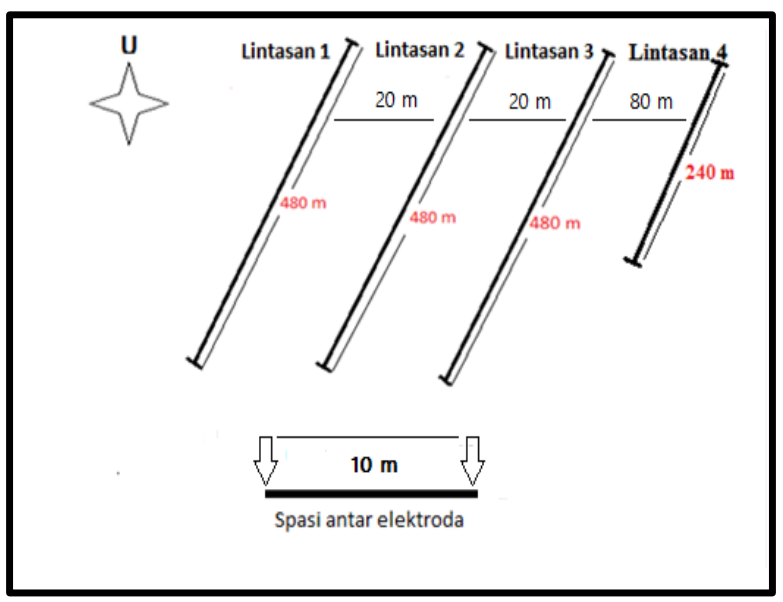

Gambar 7 Desain Survei Penelitian.

\section{HASIL DAN PEMBAHASAN}

\section{Hasil}

\section{Akuisisi Data}

Jalur lintasan pada lokasi penelitian yang sebenarnya setelah melalui proses pembentanggan kabel dilapangan dapat dilihat seperti pada Gambar 8.

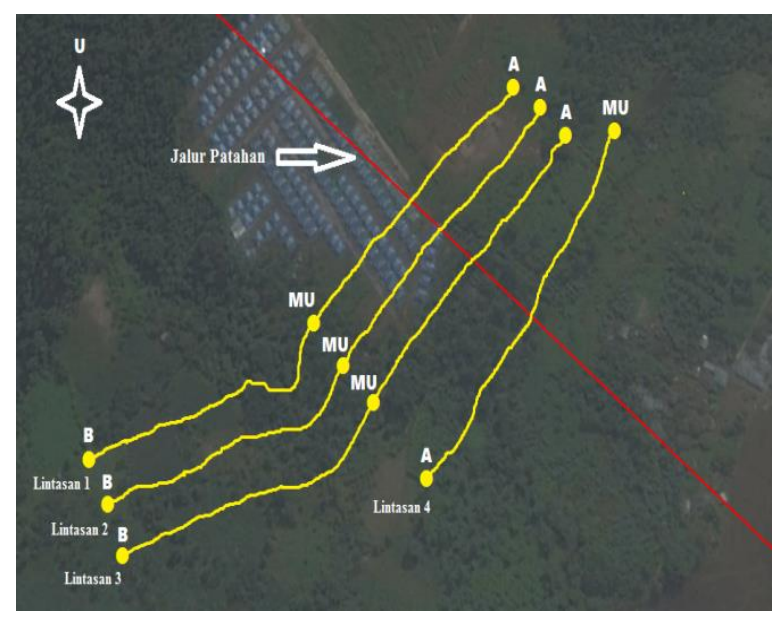

Gambar 8 Peta posisi lintasan terhadap jalur patahan.

Bentangan kabel untuk lintasan 1, 2 dan 3 adalah 480 meter dengan jarak masing-masing antar elektroda adalah sebesar 10 meter, sehingga total keseluruhan elektroda adalah 48 buah untuk satu lintasan. Sedangkan bentangan kabel untuk Lintasan 4 sebesar 240 meter dengan spasi antara elektroda sebesar 10 meter. 
Pengambilan data dilakukan dengan membentangkan kabel sepanjang 480 meter (untuk lintasan 1 - 3) dan 240 meter (untuk lintasan 4), dimana proses pembentangan kabel dumulai dari titik dimana main unit diletakan. Lama pengambilan data untuk tiap-tiap lintasan bervariasi tergantung dari medan yang dilewati jalur lintasan serta jenis struktur bawah permukaan tanah. Medan pada lokasi penelitian cenderung berbukit dan berlembah, dimana pepohonan dan rumput-rumput liar cenderung mendominasi lahan pada lokasi penelitian. Alat yang digunakan adalah seperangkat Multichannel and multielectrode resistivity Ip Meter MAE X612-EM dengan menggunakan konfigurasi Wenner-Schlumberger.

\section{Analisis Patahan Pada Lintasan 1}

Pada lintasan 1 tidak menunjukan ciri-ciri adanya patahan (sesar), namun memperlihatkan adanya rekahan (kekar). Indikasi dari adanya rekahan pada lintasan 1 ditandai oleh adanya zona-zona lemah (zona yang memiliki harga resistivitas kecil) yang menempati citra 2 dimensi bawah permukaan pada lintasan 1 . Diduga bahwa rekahan terletak pada jarak 80 dan 210 meter dari titik awal pengukuran atau berada pada jarak $20 \mathrm{~m}$ sebelah timur laut dan $100 \mathrm{~m}$ sebelah barat daya dari jalur patahan dengan kedalaman yang sama kurang lebih 0-30 meter dari permukaan tanah. Nilai resistivitas dari zona-zona lemah tersebut yang kemudian diindikasikan sebagai rekahan berada pada kisaran 7 - $50 \Omega \mathrm{m}$. Pola pendugaan rekahan pada lintasan 1 dapat dilihat pada Gambar 9.

\section{Analisis Patahan Pada Lintasan 2}

Pada lintasan 2 juga tidak terlihat adanya ciriciri patahan (sesar) melainkan rekahan (joint). Zona lemah pada lintasan 2 yang diindikasikan sebagai rekahan atau retakan terdapat pada bentangan elektroda yang ke 8 (80 meter dari titik awal lintasan) atau 20 meter sebelah timur laut dari jalur patahan dengan posisi vertikal berada pada kedalaman 0 - 30 meter dari permukaan tanah. Harga resistivitas dari zona lemah yang diindikasikan sebagai rekahan/retakan berada pada kisaran $30-60$ $\Omega \mathrm{m}$. Pola pendugaan rekahan pada lintasan 2 dapat dilihat seperti pada Gambar 10.

\section{Analisis Patahan Pada Lintasan 3}

Pada lintasan 3 dugaan kedudukan rekahan berada pada posisi 80 dan 210 meter dari titik awal bentangan atau berada pada jarak 20 meter sebalah timur laut jalur patahan dan 100 meter sebelah barat daya dari jalur patahan. Zona-zona lemah tersebut masing-masing mempunyai kedalaman yang relatif sama, yaitu berkisar antara 0 - 30 meter dari permukaan tanah dan memiliki harga resistivitas berkisar antara $0-80$

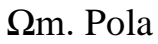

\section{Analisis Patahan pada Lintasan 4}

Pada lintasan 4 juga tidak terdapat adannya struktur batuan yang dindikasikan sebagai patahan (sesar), melainkan memeprlihatkan adanya struktur rekahan atau retakan (joint). Hal tersebut ditandai oleh zona-zona lemah yang memiliki harga resistivitas yang relatif kecil berkisar antara $0-40 \Omega \mathrm{m}$. Indikasi rekahan tersebut berada pada jarak $130 \mathrm{~m}$ dari titik awal bentangan atau berada pada jarak 20 meter dari jalur patahan, dengan kedalaman kurang lebih sebesar 0 - 30 meter dari permukaan tanah. Pola pendugaan rekahan pada lintasan 4 dapat dilihat seperti pada Gambar 12. 


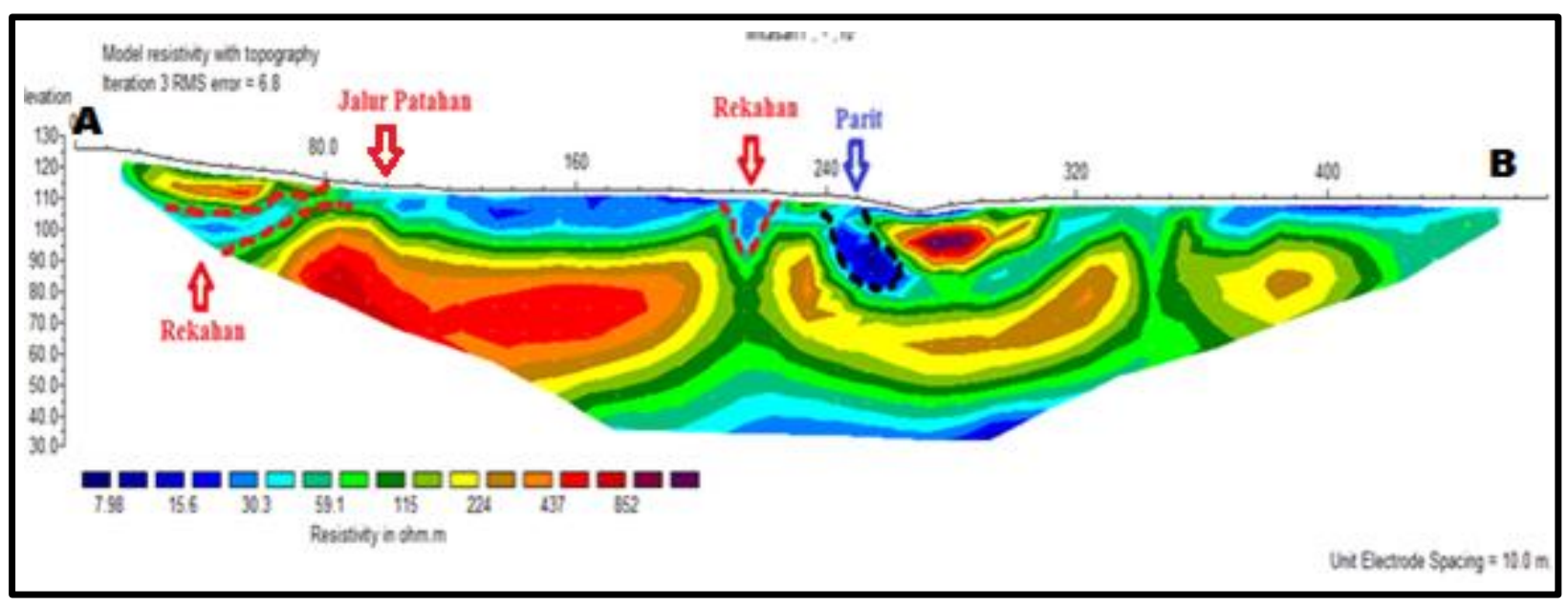

Gambar 9 Dugaan keberadaan rekahan pada Lintasan 1

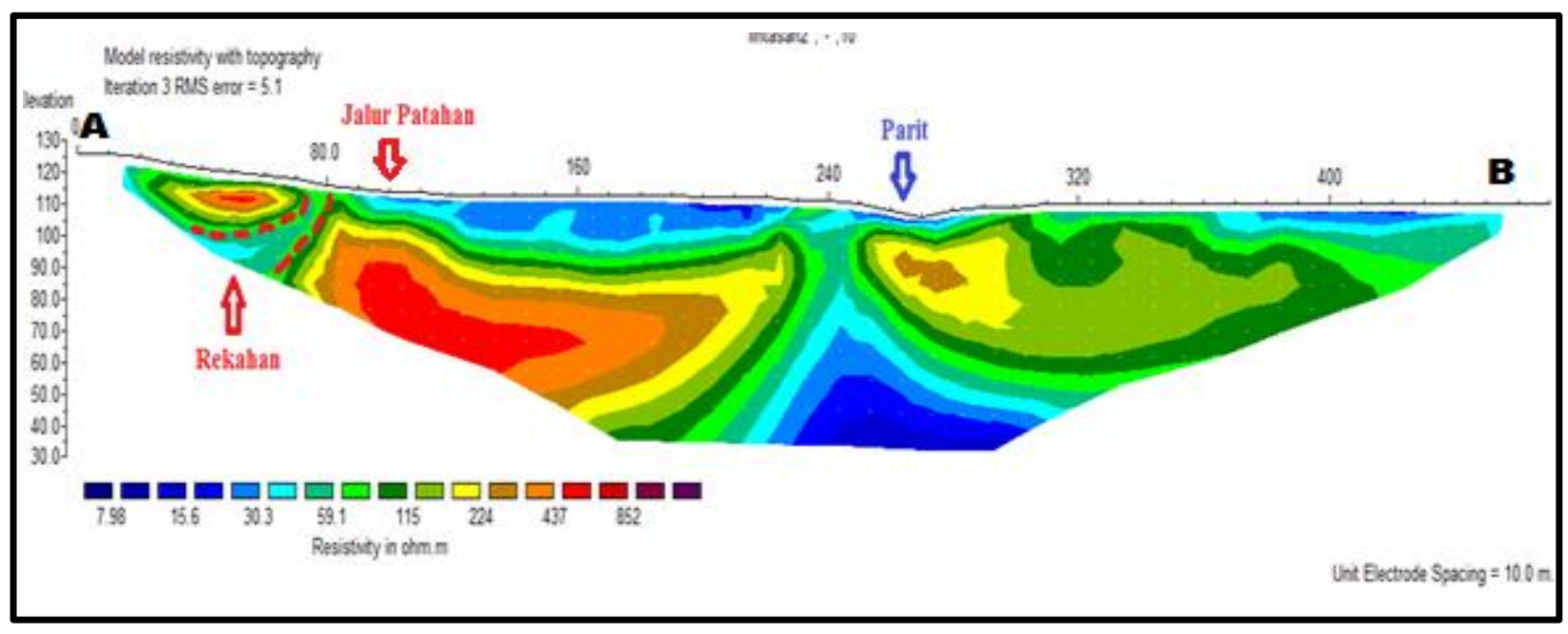

Gambar 10 Dugaan keberadaan rekahan pada Lintasan 2

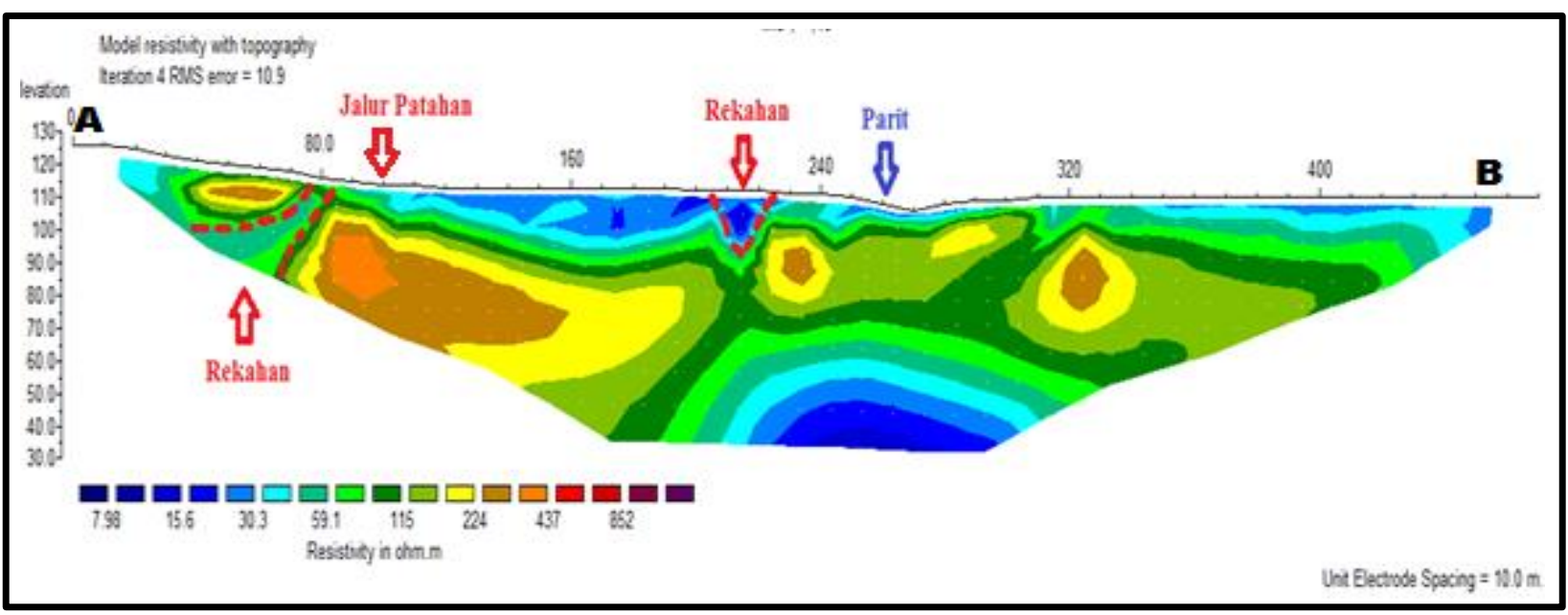

Gambar 11 Dugaan keberadaan rekahan pada Lintasan 3 


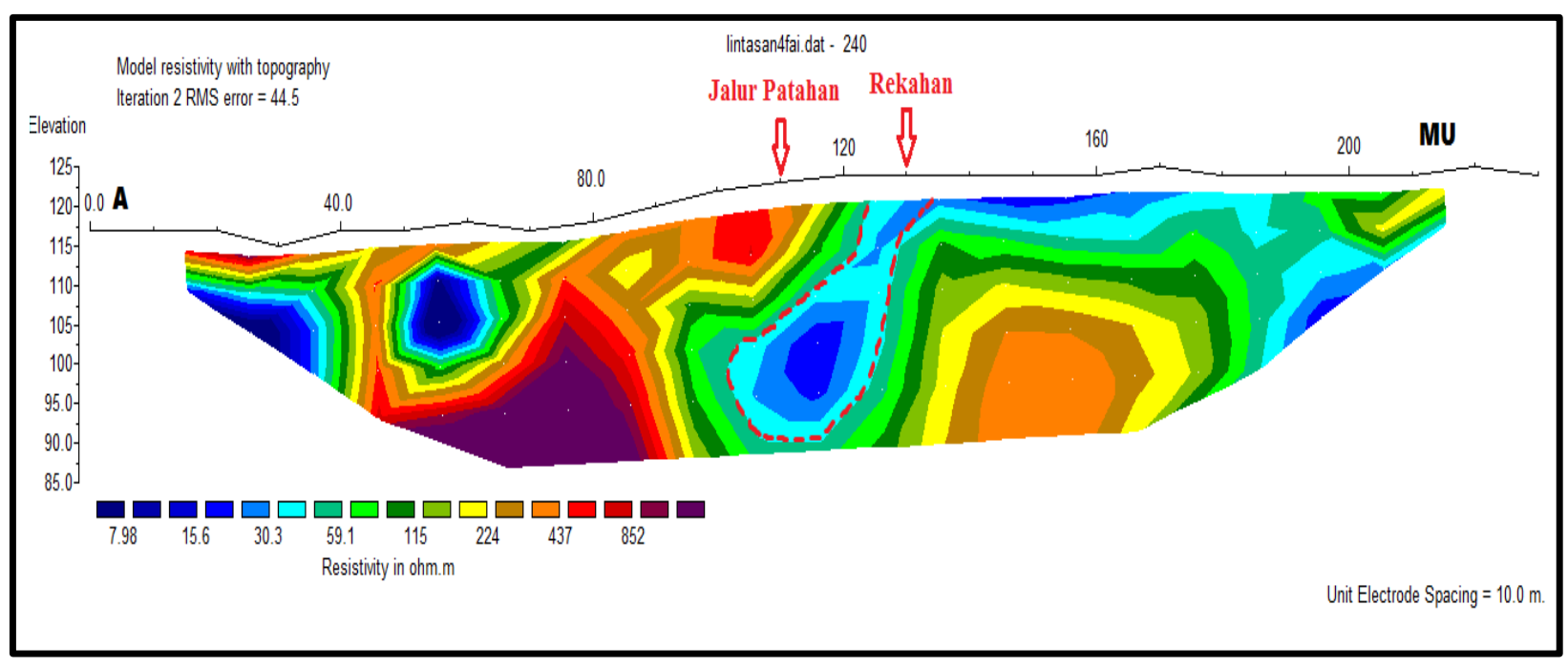

Gambar 12 Dugaan keberadaan rekahan pada Lintasan 4

\section{Pembahasan}

Berdasarkan hasil dan analisis yang telah dilakukan pada Gambar 4.9 sampai 4.11 bahwa pada keempat lintasan yang ada pada lokasi penelitian tidak memperlihatka ciri-ciri yang mengindikasikan adanya patahan (Fault) melainkan rekahan (Joint) dan memiliki jenis rekahan yang bersifat terbuka (Extension Joint). Hal itu ditegaskan oleh zona-zona yang memiliki nilai resistivitas yang rendah yaitu berkisar antara $0-80 \Omega \mathrm{m}$ dan memiliki ciri-ciri sebagai rekahan. Kisaran harga resistivitas yang dijadikan acuan untuk mengindikasikan zona rekahan pada lokasi penelitian yaitu berkisar antara 0-80 $\Omega \mathrm{m}$. Kisaran tersebut relatif sama dengan penelitian yang telah dilakukan oleh (Nguyen et al, 2005) tentang Image processing of $2 D$ resistivity data for imaging fault, dimana pada penelitianya patahan yang teridentifikasi memiliki resistivitas sebesar $0-40 \Omega \mathrm{m}$. Hal yang sama juga dikemukakan oleh (Suzuki et al, 2000) dalam penelitiannya tentang Case studies of electrical and electromagnetic methods applied to mapping active faults beneath the thick quaternary, dari hasil penelitiannya tersebut Patahan Kawafune yang teridentifikasi memiliki kisaran harga resistivitas sebesar 5 $80 \Omega \mathrm{m}$.

Menurut (Price dan Cosgrove, 1990) dalam bukunya yang berjudul Analysis of Geological Structures bahwa ciri-ciri rekahan antara lain adalah struktur rekahannya memotong bidang perlapisan batuan, hal tersebut ditegaskan oleh gambar bawah permukaan yang ditampilkan oleh keempat lintasan yang tersusun parallel satu dengan yang lain dimana lokasi rekahan digambarkan berada pada kedudukan yang sama yaitu berada pada jarak 20 meter dari jalur patahan serta tegak lurus dengan keempat jalur lintasan penelitian. Ciri selanjutnya yaitu zona yang diindikasikan sebagai rekahan memiliki struktur yang terbuka dan memiliki harga resistivitas yang relatif kecil yaitu sebesar $0-80 \Omega \mathrm{m}$, hal tersebut menurut Hodgson (1961) dalam jurnalnnya tentang Classification of structures on joint surfaces adalah disebabkan oleh material-material sedimen yang memiliki densitas yang kecil dan tercampur oleh mineral yang bersifat konduktif yang mengisi ruang pada bidang rekahan sehingga mengakibatkan zona tersebut memiliki resistivitas yang kecil. Lathief (2014) juga dalam penelitiannya menjelaskan mengenai zona-zona rekahan yang terisi oleh mineral yang bersifat konduktif tersebut.

Frans et al (2015) pada penelitiannya juga menjelaskan bahwa jenis struktur patahan lembar Manado yang melewati keluran Singkil bersifat sebagai rekahan dan jenis dari rekahannya adalah Extension Joint yaitu rekahan yang bersifat terbuka dengan kisaran resistivitas sebesar $0-30 \Omega \mathrm{m}$. Hal yang sama ditegaskan oleh Utiya et al (2015) pada penelitiannya mengenai identifikasi patahan lembar Manado yang melewati Kelurahan Paal Dua, dalam 
penelitiannya tersebut memberikan kesimpulan bahwa jenis struktur patahan yang melewati daerah paal dua bersifat rekahan dengan kisaran harga resistivitas sebesar $2-90 \Omega \mathrm{m}$.

\section{KESIMPULAN DAN SARAN}

\section{Kesimpulan}

\begin{abstract}
Berdasarkan penelitian yang telah dilakukan di Kabupaten Minahasa Utara Kecamatan Kalawat Desa Watutumou II tentang Identifikasi Patahan Manado dengan menggunakan metode Geolistrik Resistivitas Konfigurasi Wenner-Schlumberger, maka dapat disimpulkan bahwa :
\end{abstract}

1. Jalur patahan Manado yang melewati Kabupaten Minahasa Utara di Desa Watutumou II diindikasikan sebagai rekahan.

2. Bidang rekahan dengan resistivitas $0-80 \Omega m$ pada empat lintasan memiliki posisi dan kedudukan yang relatif sama, yaitu pada jarak 20 meter dari jalur patahan Manado, dan berada pada kedalaman yang relatif dangkal, yaitu 0 - 30 meter dari permukaan tanah.

\section{Saran}

adalah sebagai berikut :

Saran untuk penelitian selanjutnya Penelitian ini hanya memberikan analisis berdasarkan metode geolistrik saja, untuk itu perlu ada penelitian lanjutan dengan menggunakan metode Geofisika yang lain, misalnya metode Seismik, Georadar dan metode-metode Geofisika yang lain.

\section{DAFTAR PUSTAKA}

Damayanti, F. 2013. Aplikasi Metode Geolistrik Tahanan Jenis Konfigurasi DipoleDipole Untuk Identifikasi Pencemaran Limbah Organik [Skripsi]. FMIPA UNES, Semarang.

Effendi,A.C., dan S.S. Bawono. 1997. Peta Geologi Lembar Manado Sulawesi utara, Edisi ke-2 pusat penelitian dan pengembangan Geologi, Bandung.
Frans H.S., As'ari., Gerald H. Tamuntuan., 2015. Identifikasi Patahan Manado dengan menggunakan Metode Geolistrik Konfigurasi Wenner-Schlumberger di Kota Manado, Jurnal Ilmiah Sains. 15(2) : 142-148.

Hendrajaya, L dan Simpe. I, Nengah. 1993. Respon Teoritik Elskromagnet VLF Model sesar dan Penerapanya Pada Data Elektromagnet VLF Dari Daerah Panasbumi Muaralaboh Sumatra Utara, Simposium Fisika Nasional XIV. Jurusan Fsiska-FMIPA USU, Medan.

Hodgson R.A., 1961. Classification of structures on joint surfaces. American Journal of Science. 259 : 493-502.

Ismi Lutfinur., Ratna S Wulandari., Syifaul Fauziyah., 2015. Identifikasi Zona Sesar Opak di Daerah Bantul Yogyakarta Menggunakan Metode Seismik Refraksi, Jurnal Sains dan Teknologi. 13(1) : 39 - 46

Lathief A. Fashihullisan., Adi Susilo., Agus F. Jam'an., 2014. Identifikasi Daerah Sesar dan Intrusi Berdasarkan Perbandingan Antara Filter ( RTP,Upward,Downward, dan Aniltic Signal) Data Mapping Regional Magnetik Daerah Garut Jawa Barat, Physics Student Journal 2(1) : 17

Lowrie, W. 2007. Fundamental of Geophysics. New York : Cambridge University Press.

Lutfinur, I. 2015. Identifikasi Sesar Bawah Permukaan Menggunakan Metode Geolistrik Konfigurasi Schlumberger (Studi Kasus Sungai Opak Yogyakarta) [Skripsi]. FMIPA UNES, Semarang.

Natawidjaya, D. H., 2007. Evaluasi Bahaya Patahan Aktif, Tsunami dan Goncangan Gempa. Laboratorium Riset Bencana Alam Geoteknologi - LIPI. 
Nguyen F T., Garambois S., Jongmans D., Pirard E., Loke M H., 2005. Image processing of $2 \mathrm{D}$ resistivity data for imaging faults, Journal of Applied Geophysics. 57 : (260 -277)

Noor D., 2009. Pengantar Geologi Edisi Pertama, Pakuan University Press, Bogor.

Price N.J dan Cosgrove J.W. 1990. Analysis of Geological Structures. Cambridge University Press, New York.

Sompotan F.A., 2012. Struktur Geologi Sulawesi, Perpustakaan Sains Kebumian ITB, Bandung.

Suzuki K., Toda S., Kusunoki K., Fujimitsu Y., Mogi T., Jomori A., 2000. Case studies of electrical and electromagnetic methods applied to mapping active faults beneath the thick quaternary. Department of Geology. $56: 29-45$.
Telford, W. and Sheriff., 1990. Applied Gheophysics. Camridge : Cambridge University Press, London.

Todd, D.K, 1959, Groundwater Hydrology, Associate Professor of Civil Engineering California University, John Wiley \& Sons, New York.

Twiss, R. J. And Moores, E. M. 1992. Structural geology. W.H. Freeman \& Company, New York.

Utiya J., As'ari., Seni H.J Tongkukut., 2015. Metode Geolistrik Resistivitas Konfigurasi Wenner-Schlumberger dan Konfigurasi Dipole-dopole untuk Identifikasi Patahan Manado di Kecamatan Paaldua Kota Manado. Jurnal Ilmiah Sains. 15(2) : 135-141.

Waluyo P., Utama Widya., (2009), Deteksi pola Patahan Di desa Renokenongo porong sidoarjo dengan metode geolistrik konfigurasi wenner. Laboratorium Geofisika FMIPA ITS, Surabaya. 